\title{
Utilization and Influence of Condiments Prepared From Fermented Legumes on Quality Profile of Meat
}

\author{
E. S. Apata ${ }^{1}$, O. O. Eniolorunda ${ }^{1}$, O. C. Apata $^{2} \&$ L. B. Eso ${ }^{1}$ \\ ${ }^{1}$ Meat Science Laboratory; Department of Animal Production, Olabisi Onabanjo University, Ogun State, \\ Nigeria \\ ${ }^{2}$ Department of Wildlife and Ecotourism Management, University of Ibadan, Ibadan, Oyo State, Nigeria \\ Correspondence: E. S. Apata, Meat Science Laboratory; Department of Animal Production, Olabisi Onabanjo \\ University, Ogun State, Nigeria. E-mail: ebunoluapata2008@yahoo.com
}

Received: May 19, 2014 Accepted: June 25, 2014 Online Published: July 30, 2014

doi:10.5539/jfr.v3n5p113 URL: http://dx.doi.org/10.5539/jfr.v3n5p113

\begin{abstract}
This study was conducted to investigate the utilization and influence of condiments prepared from four fermented legumes; African locust-bean (Parkia biglobosa), melon seeds (Citrullus vulgaris), soybean (Glycine max) and cotton seeds (Malvaceae gossypium). They were processed, dried, milled and $25 \%$ solution of each condiment was made using purified water. $200 \mathrm{~g}$ fresh beef from the thigh cut of White Fulani bull (Bos indicus) was purchased, divided into 4 parts of $50 \mathrm{~g}$ and $20 \mathrm{ml}$ of condiments solution was injected into each beef with a syringe and needle each condiment and $50 \mathrm{~g}$ beef constituted a treatment thus; $\mathrm{TO}=$ control (No condiment), TI $=$ Beef steak + locust bean condiment, $\mathrm{T} 2=$ Beef + melon seeds condiment, $\mathrm{T} 3=$ Beef + soybean condiment, $\mathrm{T} 4$ $=$ Beef + cotton seeds condiment. The injected beef steaks were wrapped in foil paper and broiled in oven at 170 ${ }^{\circ} \mathrm{C}$ for 20 mins. Data were collected on physicochemical, microbiological and sensory properties of processed beef and were subjected to analysis of variance (ANOVA) at $p=0.05$ in a completely randomized design experiment. The results showed that cooking loss and shear force were lower in TI, while water holding capacity (WHC) and yield were higher. Protein and ash were high in TI followed by T3 while fat and fibre were significantly lower. Aerobic and anaerobic bacteria were significantly the same across the treatments while coliform and fungal counts were lower except in T2 and T4. Treatment1 was adjudged higher in all the eating qualities except colour and was well accepted. It is therefore, recommended that locust bean condiment be used in processing meat followed by soybean condiment. However, further investigation should be carried out on varied levels of locust bean condiment to determine the level that will give better colour which can improve the meat product acceptability and consumption.
\end{abstract}

Keywords: condiments, fermented legumes, meat, quality, utilization

\section{Introduction}

Meat is the flesh of animals that contains protein, vitamins, minerals and amino-acids required for human diets, it is the closest to human flesh in terms of biochemical composition, however, it varies depending on the species breed, sex, age, plane of nutrition, exercise the animal is engaged and the anatomical location of the musculature involved (Lawries \& Ledward, 2006). A condiment in a substance that is applied to food in the form of a sauce, powder or spread in order to enhance the flavour (Oboh, 2006).

In Nigeria and some African countries, condiments such as fermented melon seed (Ogiri), fermented soybeans (Dadawa), fermented locust bean (1 ru) and fermented cotton seed (Ogiri) are commonly used to season food and meat (Barber \& Achinewhu, 1992). Fermentation of legumes is usually carried out a moist solid state, involving contact with appropriate microorganisms at the ambient temperature of the tropics and the completion of fermentation is indicated by the formation of mucilage and overtones of ammonia produced due to breakdown of amino acids (Onyenekwe et al., 2012). The proximate analysis of these condiments indicates that they could contribute of food including meat which eventually improve the daily intake of these nutrients (Omafuvbe et al., 2002).

In view of the serious need to improve the nutrients composition of foods, meat inclusive, using condiments produced from legumes would serve as flavourant and nutrient enrichment of food which eventually leads to 
more intake. It is however, observed that there is limited information on the quality of food and meat in particular processed with locally produced condiments from fermented African locust beans (Parkis biglobosa) melon seeds (Citrullus vulgaris), soybean (Glycine max) and cotton seeds (Malvaceae gossypium). This study therefore, aimed at determining the effect of condiments from these fermented legumes on quality of beef.

\section{Materials and Methods}

\subsection{Location of Study}

This study was conducted in the Meat Science Laboratory of the Department of Animal Production, Olabisi Onabanjo University, Yewa Campus, Ayetoro, Ogun State.

The four legumes used for this study African locust beans (Parkia biglobosa); melon seeds (Citrullus vulgaris), cutton seeds (Malvaceae gossypium) and soybeans (Glycine max) were purchased from Oba market in Ibadan, Oyo State, Nigeria.

\subsection{Preparation of Condiments}

Raw seeds of four legumes were boiled for $12 \mathrm{hrs}$ and excess water was drained and the seeds were dehulled by washing them in a large wooden mortar with a pestle. The seeds coats were removed by rubbing the cotyledons between the palms of the hand and washed with clean water. The cotyledons were cooked further for $2 \mathrm{hrs}$; the boiling water was drained and the cotyledons were then spread on trays, covered with another trays, and later wrapped with jute sacks and fermented for 3 to 4 days. In case of melon seeds, they were wrapped with Thaumaloccus demoelli leaves (to hasten fermentation of melon) after which the cotyledons were boiled for additional $2 \mathrm{hrs}$ and fermented for 3 to 4 days at ambient temperature (Oboh, 2006) The fermented legumes were sundried inside a netted box to shield files. They were milled and stored in clean and dry bottles and used as condiments in this study.

\subsection{Preparation of Experimental Beef Samples}

A total of $200 \mathrm{~g}$ beef steak from thigh cut of White Fulani bull was used for this study. It was purchased from Ayetoro market in Yewa North Local Government Area of Ogun State. The meat was divided into 4 parts of $50 \mathrm{~g}$ steak per treatment. $25 \%$ solution of each of 4 of the condiments was prepared by dissolving $25 \mathrm{~g}$ of each condiment in $100 \mathrm{ml}(25 \mathrm{~g} / 100)$ of distilled warm water and cooled. This was injected into $50 \mathrm{~g}$ beef steak with syringe and needle. Each condiment in beef constituted a treatment with a control treatment which were replicated 3 times.

$\mathrm{T} 0=$ Beef without condiment (control), $\mathrm{TI}=$ Beef + locust bean condiment

$\mathrm{T} 2=$ Beef + melon seed condiment, $\mathrm{T} 3=$ Beef + soybean condiment $\mathrm{T} 4=$ Beef + cotton seed condiment

Beef samples were wrapped in foil paper and broiled in the oven at $170{ }^{\circ} \mathrm{C}$ for 20 minutes to an internal temperature of $72{ }^{\circ} \mathrm{C}$ (Aduku \& Olukosi, 2000).

Proximate composition (Moisture, protein fat, crude fibre) of processed beef were determined using the standard method (AOAC, 2005).

The $\mathrm{pH}$ of processed beef was determined by homogenizing $10 \mathrm{~g}$ of processed beef for $5 \mathrm{~min}$ with $90 \mathrm{ml}$ distilled water in a blender (plate $5 \mathrm{~mm}$ ) model (242), Nakai, Japan and the $\mathrm{pH}$ measured using a portable $\mathrm{pH}$ measured using a portable $\mathrm{pH}$ meter model (H18424) Havanna instruments, Romania as described by Marchiori and defelicio (2003).

Table 1. Proximate composition of legumes used in beef processing

\begin{tabular}{lllll}
\hline Variable & \multicolumn{4}{c}{ Legumes } \\
\cline { 2 - 5 } & LB & MS & SB & CS \\
\hline Crude Protein (\%) & 35.2 & 23.6 & 44.6 & 25.0 \\
Ether Extract (\%) & 15.3 & 21.0 & 12.7 & 19.5 \\
Ash (\%) & 2.8 & 1.9 & 1.8 & 3.0 \\
Crude fibre (\%) & 9.2 & 7.8 & 5.9 & 20.8 \\
\hline
\end{tabular}

Source: (Oboh, 2006).

$\mathrm{LB}=$ Locus beans, $\mathrm{MS}=$ Melon seeds, $\mathrm{SB}=$ Soybeans, $\mathrm{CS}=$ Cotton seeds. 


\subsection{Cooking Loss and Thermal Shortening}

Cooking loss was measured by removing approximately $10 \mathrm{~g}$ and $6 \mathrm{~cm}$ long meat sample from each treatment, wrapped in air tight polythene bags with a thermometer $\left(110^{\circ} \mathrm{C}\right)$ inserted in the meat and cooked in water in a pre-heated cooking pot for 20 min. on and adjustable Pifco Japan Electric "hot" plate Model No. ECP 2002 until the geometric centre of the meat samples was heated to $72^{\circ} \mathrm{C}$ (Malgorzata et al., 2005). Meat samples were removed from the pot and cooled to room temperature $\left(27^{\circ} \mathrm{C}\right)$. They were reweighed and the difference in weight recorded as percentage cooking loss as follows:

$$
\text { Cooking loss }=\frac{\text { Initial wt. of meat }- \text { Final wt. of meat }}{\text { Initial Wt. of meat }} \times 100
$$

Thermal shortening of the meat samples was measured with the same meat samples used to measure cooking loss. The lengths of meat samples were remeasured after cooking and cooling, the difference in length was expressed as thermal shortening following the modified method of Malgorzata et al. (2005). Thus:

$$
\text { Thermal shortening }=\frac{\text { Initial length of meat }- \text { Final length of meat }}{\text { Initial length of meat }} \times 100
$$

\subsection{Cold Shortening}

This was measured by placing $10 \mathrm{~g}$ and $8 \mathrm{~cm}$ long processed meat from each treatment in a freezer at $-180^{\circ} \mathrm{C}$ for 24 hours. The length of the meat were re-measured the difference in length was expressed as cold shortening following the procedures described by Hedrick et al. (1994) thus:

$$
\text { cold shortening }=\frac{\text { Initial length of meat }- \text { Final length of meat }}{\text { Initial length of meat }} \times 100
$$

\subsection{Percentage Cooking Yield}

This was obtained by substracting the value of percentage cooking loss from $100 \%$ and the remainder recorded as the percentage cooking yield according to Omojola (2008).

Thus: Cooking yield $=100 \%-\%$ cooking loss

\subsection{Drip Loss}

This was determined following the procedures of Insausti et al. (2001). Weight of an empty polythene bag was taken (Wp) Meat sample (10 g) was weighed and put into the bag $(\mathrm{Wp}+\mathrm{M})$ and stored in a refrigerator at $4{ }^{\circ} \mathrm{C}$ for $48 \mathrm{~h}$. The meat sample was removed from the refrigeration and the weight of the bag plus the juice drained by the meat sample were measured $(\mathrm{Wp}+\mathrm{j})$. drip loss was expressed as percentage of the initial weight of the meat sample, thus:

$$
\text { Drip loss }=\frac{(W p+j)-(W p)}{(W p+m)-(W p)} \times 100
$$

\subsection{Water Holding Capacity (WHC)}

An approximately $1 \mathrm{~g}$ of meat sample from each treatment was placed between two $9 \mathrm{~cm}$ Whatman No 1 filter papers (Model C, Caver Inc. Wabash, USA). The meat sample was pressed between two $10.2 \times 10.2 \mathrm{~cm}^{2}$ plexiglasses at about $35.2 \mathrm{~kg} / \mathrm{cm}^{3}$ absolute pressure for 1 minute with a vice (Suzuki et al., 1991). The meat sample was removed and oven dried between $100-105^{\circ} \mathrm{C}$ for $24 \mathrm{~h}$ to determine the moisture content of the meat sample. The amount of water released from the meat sample was measured indirectly by measuring the area of filter paper welted relative to the area of pressed meat sample.

Thus:

$\mathrm{Aw}=$ Area of water released from meat sample $\left(\mathrm{cm}^{2}\right)$

$$
\mathrm{WHC}=\frac{100-(\mathrm{Aw}-\mathrm{Am}) \times 9.47}{\mathrm{Wm} \times \mathrm{Mc}} \times 100
$$

$\mathrm{Am}=$ Area of meat sample $\left(\mathrm{cm}^{2}\right)$

$\mathrm{Wm}=$ Weight of meat sample $(\mathrm{g}) \mathrm{Mc}=$ Moisture content of meat sample $(\%)$

$9.47=$ A constant factor. 


\subsection{Shear Force}

Weighed meat samples from each treatment $(10 \mathrm{~g})$ was wrapped in polythene bags and cooked in a pre-heated cooking pot for $20 \mathrm{~min}$ on an adjustable Pifco Japan Electric hot plate Model NECP 202 to an internal temperature of $72{ }^{\circ} \mathrm{C}$. They were removed and cooled to room temperature $\left(27^{\circ} \mathrm{C}\right)$ for $10 \mathrm{~min}$, reweighed, bagged and chilled at $4{ }^{\circ} \mathrm{C}$ for $18 \mathrm{~h}$. They were equilibrated to room temperature and $1.25 \mathrm{~cm}$ diameter cores parallel to muscle fibre orientation were removed with a coring device (Qiaofen \& Da-Wen, 2005). The meat samples were sheared at three locations with Warner Bratzler V-notch blade shearing instrument according to Honikel (1998) and average value of the three shearing was taken.

\subsection{Microbiological Analysis}

$10 \mathrm{~g}$ of was blended with $90 \mathrm{ml}$ of $0.1 \%$ (W/V) peptone water for 60Sec using a Nakai Japan blender model 242 . Dilutions were made with $0.1 \%$ peptone water and diluted homogenate of each sample was spread on duplicate petri-plates. Microbial counts were obtained as follows; aerobic plate on Blood agar (Difco, USA) incubated at $32{ }^{\circ} \mathrm{C}$ for $48 \mathrm{hrs}$. Enteobacteriaceae (coliform) on Violet Red Glucose Agar (Ditco, USA) over laid with the same medium and incubated at $37^{\circ} \mathrm{C}$ for $24 \mathrm{hrs}$, Lactic acid bacteria onlactobacilli MRS Broth, Bacto Agar and glacial acetic acid (pancrease) and incubated at $32^{\circ} \mathrm{C}$ for $48 \mathrm{hrs}$, while fungal count was done on potato dextrose Agar (Fluka Lek) incubated at $30^{\circ} \mathrm{C}$ for 5 days. All analysis were carried out following the procedures described by ICMSF (1986), APHA (1992) and AOAC (2000).

\subsection{Sensory Evaluation}

10 member semi-trained taste panel was used following the procedures of AMSA (1995). The panelists were provided unsalted biscuits and water to change their taste between treatment beef samples. Beef samples were coded before broiling and were presented to the panelists sequentially and were evaluated independently of the other. The panelists rated the beef samples on a 9-point hedonic scale on which $9=$ like very much and $1=$ dislike very much for colour, aroma, flavour, tenderness, juiciness, texture and overall acceptability.

\subsection{Statistical Analysis}

All data collected from this study were subjected to analysis of variance (ANOVA) at $p=0.05$ in a completely randomized design experiment using (SAS, 2002). Significant means were separated with Duncan multiple range test of the same system.

\section{Results and Discussion}

The condiments affected the physical properties of processed beef significantly $(\mathrm{p}<0.05)$ as shown on Table 2 . Cooking and drip losses, thermal and cold shortenings as well as shear force values were higher $(\mathrm{p}<0.05)$ in T0 followed by T4 and lower $(\mathrm{p}<0.05)$ in TI, while cooking yield and water holding capacity (WHC) were higher $(\mathrm{p}<0.05)$ in T1 than in T0 and T4 respectively. Apata et al. (2011) reported that WHC has significant influence on physical characteristics of meat in that when it was higher, cooking yield increased, shear force decreased which made the meat more chewable and preferable due to tenderness of the meat. The results obtained from this study revealed that beef processed with condiment from fermented bean locust bean (Parkia biglobosa) favoured higher WHC in meat and therefore, higher yield than condiments from other fermented legumes tested in this study. Table 3 shows the results of biochemical composition and $\mathrm{pH}$ of beef processed with condiments from fermented legumes. It was revealed that beef processed with condiment from fermented locust bean (TI) and Soybean (T3) had the same ( $>0.05$ ) protein profile (Table 3). Beef without condiment treatment (T0) followed by that treated with condiment from locust bean $(\mathrm{T} 1)$ elicited the least $(\mathrm{P}<0.05)$ fat, Table 3 while the ash contents were higher $(\mathrm{p}<0.05)$ in $\mathrm{T} 1$ and T4 followed by T2 and T3 but least $(\mathrm{p}<0.05)$ in TO. Crude fibre was lower $(\mathrm{P}<0.05)$ in TO and increased in T1 to T3 and was highest $(\mathrm{p}<0.05)$ in $\mathrm{T} 4$ while the $\mathrm{pH}$ of processed beef was the same $(p>0.05)$ in all the treated beef, but was significantly $(p<0.05)$ lower in TO. The results of biochemical composition obtained in this study reflected what (Oboh, 2006) reported. The higher ash content observed in $\mathrm{T} 1$ indicated that condiment from locust bean might contain high mineral content.

The microbial load profile of beef processed with condiments from fermented legumes is presented on Table 4 . The control treatment $(\mathrm{T} 0)$ showed the least $(\mathrm{p}<0.05)$ aerobic and anaerobic bacteria while treatments $\mathrm{T} 1, \mathrm{~T} 2, \mathrm{~T} 3$ and T4 gave higher $(\mathrm{p}<0.05)$ numbers of these bacteria, but coliform bacteria were higher $(\mathrm{p}<0.05)$ in $\mathrm{T} 0$ than in $\mathrm{T} 1, \mathrm{~T} 2, \mathrm{~T} 3$ and T4, however, T2 and T4 gave higher $(\mathrm{p}<0.05)$ fungal load than in T1, T3 and T0 with least $(\mathrm{p}<0.05)$ of fungal count. Apata et al. (2013) reported that both aerobic and anaerobic bacteria proliferate at best conducive environment which in this case is fermentation. It appeared that coliform bacteria could not favourably compete with these microbes but could only survived more on untreated beef (T0) hence its larger population on control treatment. The larger number of fungal population on T2 and T4 might be due to the fact 
that melon and cotton seeds are prone to fungal attack and could be carried on raw materials used for preparing condiment since the processed beef was not preserved to warrant high numbers of fungal count as obtained in this study. However, the counts of all the microbes recorded from this study were still not above the safe levels for consumption of the meat product (Insausti et al., 2001). The taste panelists rated T2 and T3 higher $(\mathrm{p}<0.05)$ for colour followed by T1 while T0 and T4 were rated lower $(\mathrm{p}<0.05)$. T1 was rated higher $(\mathrm{p}<0.05)$ for aroma, flavour, tenderness, juiciness texture and overall acceptability followed by T3 while T0 was rated least $(\mathrm{p}<0.05)$. It was reported by Aduku and Olukosi (2000) that colour, flavour, texture and aroma are most critical in any meat product acceptability, the results obtained from this study agreed with their findings as beef processed with condiments from locust bean (TI) and soybean (T3) furnished these characteristics hence high acceptability than those in control (T0), $\mathrm{T} 2$ and $\mathrm{T} 4$ respectively.

Table 2. Physical properties of processed beef

\begin{tabular}{llllll}
\hline \multicolumn{5}{c}{ Treatments } \\
\hline Variable & TO & T1 & T2 & T3 & T4 \\
\hline Cooking loss (\%) & $52.49 \pm 0.03^{\mathrm{a}}$ & $30.00 \pm 0.50^{\mathrm{e}}$ & $45.58 \pm 0.50^{\mathrm{c}}$ & $35.03 \pm 0.14^{\mathrm{a}}$ & $50.00 \pm 0.50^{\mathrm{b}}$ \\
Cooking yield (\%) & $47.51 \pm 0.26^{\mathrm{e}}$ & $70.00 \pm 0.30^{\mathrm{a}}$ & $54.42 \pm 0.62^{\mathrm{c}}$ & $64.97 \pm 0.41^{\mathrm{b}}$ & $52.00 \pm 0.48^{\mathrm{d}}$ \\
Thermal shortening (\%) & $57.50 \pm 0.02^{\mathrm{a}}$ & $36.00 \pm 0.50^{\mathrm{e}}$ & $40.00 \pm 0.50^{\mathrm{c}}$ & $38.00 \pm 0.05^{\mathrm{d}}$ & $42.12 \pm 0.29^{\mathrm{b}}$ \\
Drip loss (\%) & $9.20 \pm 0.25^{\mathrm{a}}$ & $4.23 \pm 3.33^{\mathrm{e}}$ & $7.00 \pm 0.26^{\mathrm{c}}$ & $5.25 \pm 0.27^{\mathrm{d}}$ & $8.00 \pm 0.10^{\mathrm{b}}$ \\
Cold shortening \% & $4.07 \pm 0.03^{\mathrm{a}}$ & $2.00 \pm 0.50^{\mathrm{c}}$ & $3.20 \pm 0.50^{\mathrm{b}}$ & $2.20 \pm 0.50^{\mathrm{c}}$ & $3.87 \pm 0.32^{\mathrm{a}}$ \\
WHC (\%) & $32.00 \pm 7.34^{\mathrm{e}}$ & $62.55 \pm 1.00^{\mathrm{a}}$ & $56.00 \pm 5.00^{\mathrm{c}}$ & $60.30 \pm 5.00^{\mathrm{b}}$ & $45.00 \pm 1.00^{\mathrm{a}}$ \\
Shear force (N) & $5.60 \pm 0.30^{\mathrm{a}}$ & $3.10 \pm 0.20^{\mathrm{c}}$ & $5.30 \pm 0.38^{\mathrm{a}}$ & $4.10 \pm 0.29^{\mathrm{b}}$ & $5.42 \pm 0.35^{\mathrm{a}}$ \\
\hline
\end{tabular}

abcde: Means on the same row with different superscripts are statistically significant $(\mathrm{p}<0.05)$.

WHC $=$ Water Holding capacity.

Values after \pm are standard deviation.

Table 3. Biochemical composition of processed beef

\begin{tabular}{llllll}
\hline \multicolumn{7}{c}{ Treatments } \\
\hline Variable & TO & T1 & T2 & T3 & T4 \\
\hline Moisture (\%) & $57.30 \pm 0.20^{\mathrm{a}}$ & $51.20 \pm 0.15^{\mathrm{c}}$ & $53.27 \pm 0.21^{\mathrm{b}}$ & $50.30 \pm 0.10^{\mathrm{a}}$ & $53.43 \pm 0.05^{\mathrm{b}}$ \\
Crude proteins (\%) & $19.20 \pm 0.10^{\mathrm{c}}$ & $22.57 \pm 0.01^{\mathrm{a}}$ & $20.07 \pm 0.06^{\mathrm{c}}$ & $23.03 \pm 0.01^{\mathrm{a}}$ & $21.20 \pm 0.10^{\mathrm{b}}$ \\
Ether Extract (fat) (\%) & $8.00 \pm 0.06^{\mathrm{e}}$ & $9.07 \pm 0.36^{\mathrm{a}}$ & $15.23 \pm 0.08^{\mathrm{a}}$ & $10.20 \pm 0.05^{\mathrm{c}}$ & $12.43 \pm 0.12^{\mathrm{b}}$ \\
Ash content (\%) & $2.07 \pm 010^{\mathrm{c}}$ & $5.70 \pm 0.05^{\mathrm{a}}$ & $3.20 \pm 0.19^{\mathrm{b}}$ & $3.57 \pm 0.17^{\mathrm{b}}$ & $5.30 \pm 0.15^{\mathrm{a}}$ \\
NFE (\%) & $13.40 \pm 0.06^{\mathrm{a}}$ & $11.19 \pm 0.13^{\mathrm{c}}$ & $7.93 \pm 0.20^{\mathrm{a}}$ & $12.53 \pm 0.15^{\mathrm{b}}$ & $7.14 \pm 0.23^{\mathrm{a}}$ \\
Crude fibre (\%) & $0.03 \pm 0.70^{\mathrm{c}}$ & $0.27 \pm 0.24^{\mathrm{b}}$ & $0.30 \pm 0.21^{\mathrm{b}}$ & $0.37 \pm 0.19^{\mathrm{b}}$ & $0.50 \pm 0.17^{\mathrm{a}}$ \\
pH & $5.20 \pm 0.00^{\mathrm{b}}$ & $6.43 \pm 0.06^{\mathrm{a}}$ & $6.20 \pm 0.00^{\mathrm{c}}$ & $6.50 \pm 0.00^{\mathrm{a}}$ & $6.30 \pm 0.00^{\mathrm{a}}$ \\
\hline
\end{tabular}

abcde: Means on the same row with different superscripts are statistically significant $(\mathrm{p}<0.05)$.

NFE $=$ Nitrogen Free Extract.

Values after \pm are standard deviation.

Table 4. Microbial count for processed beef

\begin{tabular}{llllll}
\hline \multicolumn{5}{c}{ Treatments } & \\
\hline Variable & TO & T1 & T2 & T3 & T4 \\
\hline Aerobic count & $3.30 \times 10^{\mathrm{b}} \pm 0.05^{\mathrm{b}}$ & $4.43 \times 10^{\mathrm{b}} \pm 0.10^{\mathrm{a}}$ & $4.33 \times 10^{\mathrm{b}} \pm 0.05^{\mathrm{a}}$ & $4.50 \times 10^{\mathrm{6}} \pm 1.00^{\mathrm{a}}$ & $4.43 \times 10^{\mathrm{b}} \pm 0.00^{\mathrm{a}}$ \\
Anaerobic count & $3.80 \times 10^{5} \pm 1.00^{\mathrm{b}}$ & $5.40 \times 10^{5} \pm 1.00^{\mathrm{a}}$ & $5.33 \times 10^{5} \pm 0.05^{\mathrm{a}}$ & $5.23 \times 10^{5} \pm 0.05^{\mathrm{a}}$ & $5.90 \times 10^{5} \pm 0.00^{\mathrm{a}}$ \\
Coliform count & $4.60 \times 10^{5} \pm 0.07^{\mathrm{a}}$ & $3.35 \times 10^{5} \pm 0.07^{\mathrm{b}}$ & $3.50 \times 10^{5} \pm 1.00^{\mathrm{b}}$ & $3.40 \times 10^{5} \pm 1.00^{\mathrm{b}}$ & $3.60 \times 10^{5} \pm 1.00^{\mathrm{b}}$ \\
Fungal count & $2.20 \times 10^{4} \pm 1.00^{\mathrm{c}}$ & $3.30 \times 10^{4} \pm 1.00^{\mathrm{b}}$ & $4.50 \times 10^{4} \pm 0.05^{\mathrm{a}}$ & $3.23 \times 10^{4} \pm 0.05^{\mathrm{b}}$ & $4.70 \times 10^{4} \pm 1.00^{\mathrm{a}}$ \\
\hline
\end{tabular}

abc: Means on the same row with different superscripts are statistically significant $(\mathrm{p}<0.05)$.

Values after \pm are standard deviation. 
Table 5. Scores for sensory properties of processed beef

\begin{tabular}{llllll}
\hline \multicolumn{5}{c}{ Treatments } \\
\hline Variable & TO & T1 & T2 & T3 & T4 \\
\hline Colour & $4.20 \pm 0.10^{\mathrm{c}}$ & $5.30 \pm 0.10^{\mathrm{b}}$ & $6.57 \pm 0.10^{\mathrm{a}}$ & $6.70 \pm 0.01^{\mathrm{a}}$ & $3.57 \pm 0.05^{\mathrm{c}}$ \\
Aroma & $3.53 \pm 0.06^{\mathrm{a}}$ & $6.80 \pm 0.02^{\mathrm{a}}$ & $4.57 \pm 0.12^{\mathrm{c}}$ & $5.60 \pm 0.06^{\mathrm{b}}$ & $2.35 \pm 0.10^{\mathrm{e}}$ \\
Flavour & $3.57 \pm 0.11^{\mathrm{d}}$ & $6.85 \pm 0.10^{\mathrm{a}}$ & $4.60 \pm 0.10^{\mathrm{c}}$ & $5.57 \pm 0.10^{\mathrm{b}}$ & $2.40 \pm 0.06^{\mathrm{e}}$ \\
Tenderness & $3.40 \pm 0.00^{\mathrm{a}}$ & $6.40 \pm 0.06^{\mathrm{a}}$ & $4.45 \pm 0.11^{\mathrm{c}}$ & $5.40 \pm 0.06^{\mathrm{b}}$ & $4.50 \pm 0.10^{\mathrm{c}}$ \\
Juicinese & $3.24 \pm 0.10^{\mathrm{c}}$ & $5.80 \pm 0.10^{\mathrm{a}}$ & $4.70 \pm 0.10^{\mathrm{b}}$ & $4.60 \pm 0.05^{\mathrm{b}}$ & $3.70 \pm 0.11^{\mathrm{c}}$ \\
Texture & $4.00 \pm 0.26^{\mathrm{c}}$ & $5.75 \pm 0.06^{\mathrm{a}}$ & $4.60 \pm 0.07^{\mathrm{b}}$ & $4.30 \pm 0.10^{\mathrm{b}}$ & $3.00 \pm 0.10^{\mathrm{a}}$ \\
Acceptability & $4.10 \pm 0.26^{\mathrm{a}}$ & $7.60 \pm 0.10^{\mathrm{a}}$ & $5.25 \pm 0.10^{\mathrm{c}}$ & $6.37 \pm 0.15^{\mathrm{b}}$ & $3.00 \pm 0.12^{\mathrm{e}}$ \\
\hline
\end{tabular}

abcde: Means on the same row with different superscripts are statically significantly $(\mathrm{P}<0.05)$.

Values after \pm are standard deviation.

\section{Conclusion}

The results obtained from this study showed that condiments from locust bean, melon seeds and soybean can be used to process meat (beef). But it was observed that condiments from locust bean was best as it furnished better physicochemical characteristics and higher eating qualities followed by soybean. It is hereby recommended that locust bean condiment should be preferred to condiment from soybean and other fermented legumes used in this study, but further study should be conducted using varied levels of locust bean condiment in order to ascertain which level of the fermented locust bean will furnish better colour that can improve meat product processed with it thus induce more acceptability.

\section{References}

Aduku, A. O., \& Olukosi, J. O. (2000). Animal Products Processing and Handling in the Tropics. Living Books Series GU Publication, Abuja, Nigeria, pp. 24-32.

AMSA. (1995). Research Guidelines for Cookery, Sensory evaluation and Instrumental measurements of fresh meat. National Livestock and Meat Board Chicago, IL; USA.

AOAC. (2000). Official Method of Analysis (19th ed). Assoc. Official and Chemi. Inter. Inc. Washington DC. USA.

Apata, E. S. (2011). Quality attributes of Red Sokoto buck meat as influenced by post-slaughter processing methods. Ph.D Thesis in the Department of Animal Science, University of Ibadan, Nigeria.

Apata, E. S. Kuku, I. A., Apata, O. C., \& Adeyemi, K. O. (2013). Evaluation of Suya (tsire) -An intermediate moisture meat product in Ogun State, Nigeria. J. Food Res, 2(1), 87-93.

APHA. (1992). Compendium of method for the microbiological examination of foods (3rd ed) American public Health Association (eds) Vanderzant C. and D.F. Splitlstoesser Ann Arbor, Michigan, U.S.A

Barber, L. I., \& Achinewhu, S. C. (1992). Microbiology of Ogiri production from melon seeds (Citrullus vulgaris). Nig. Food J., 10, 129-135.

ICMSF. (1986). Microorganisms in Food 2. Sampling for microbiologial Analysis. Principles and Specific Application (2nd ed). Canada: University of Toronto Press.

Insausti, K., Berian, M. J., Purroy, A., Alberti, P., Gorraiz, C., \& Alzueta, M. J. (2001). Shelf life of beef from local Spanish cattle breeds stored under modified atmosphere. Meat Sci., 5, 273-281.

Lawrie, R. A., \& Ledward, D. A. (2006). Lawrie's Meat Science (7th ed). UK: Cambridge Wood Head Publishing Ltd.

Marchiori, A. F., \& de Felicio, P. E. (2003). Quality of Wild boar meat and commercial Pork. Sci. Agric (Piracicaba, Braz.), 60(1), 1-10.

Oboh, G. (2006). Nutrient and antinutrient composition of condiments produced from some fermented underutilized legumes. J. Food Bioch, 30, 579-588.

Omafuvbe, B. O., Abiose, S. H., \& Shonukan, O. O. (2002). Fermentation of Soybean (Glycine max) for Soy daddawa production by starter cultures of bacillus. Food microbiol., 19, 561-566.

Onyenekwe, P. C., Odeh, C., \& Nweze, C. C. (2012). Volatile constituents of Ogiri, Soybean daddawa and locust 
bean daddawa three fermented Nigeria food flavour enhancers. Elec. J. envtal. Agric. \& Food Chem, 15, 22. SAS. (2002). Statistical Analysis System SAS /Stat User's Guide version 9 SAS Institute Inc, Gary, NC, USA.

\section{Copyrights}

Copyright for this article is retained by the author(s), with first publication rights granted to the journal.

This is an open-access article distributed under the terms and conditions of the Creative Commons Attribution license (http://creativecommons.org/licenses/by/3.0/). 